\title{
Non-Hematopoietic Stem Cell Research
}

National Cancer Institute

\section{Source}

National Cancer Institute. Non-Hematopoietic Stem Cell Research. NCI Thesaurus. Code C16202.

General research on non-hematopoietic stem cells and their use in medicine. 